\title{
水利水电工程设计中常见问题及对策研究
}

\author{
谢欣菲 \\ DOI:10.32629/btr.v3i8.3320
}

\begin{abstract}
[摘 要] 水利水电工程是我国社会基础建设的重要部分,其施工质量对我国人民的生活生产有着较大 的影响, 需要严格做好工程设计和工程建设方面的质量控制, 尽可能减少质量问题的发生, 保证水利水电 工程的正常运行。但是在实际的水利水电工程设计中,普遍存在各种各样的问题,比如事前的准备工作不 到位、施工设计人员的综合素质有待提升、工程施工技术不够先进等等,这些都影响到水利水电工程的 施工质量, 需要采取有效对策进行处理, 促进水利水电工程的不断发展。鉴于此, 本文就针对水利水电工 程设计中的常见问题进行分析, 并提出一些具体的改进对策, 希望为水利水电工程设计人员提供一些有 效参考依据。
\end{abstract}

[关键词] 水利水电工程; 工程设计; 常见问题; 对策

中图分类号：TV; TB21 文献标识码：A

近年来, 随着我国城市化建设的快 速发展, 水利水电工程的建设步伐也逐 渐加快, 在增加水利水电工程建设投入 的同时, 对水利水电工程的质量管理提 出了更加严格的要求。而水利水电工程 的设计是否合理直接影响着整个工程施 工的顺利进行, 一旦在某个环节存在问 题, 势必会影响到工程的施工效率及施 工质量, 给施工单位带来较大的损失。 因此, 有必要深入分析水利水电工程设 计中的常见问题, 探究水利水电工程设 计的改进对策, 从而提高工程设计的水 平, 促进水利水电工程施工质量的有效 提升。

1 水利水电工程设计中的常见 问题分析

1. 1事前准备工作不到位

首先, 在进行水利水电工程设计的 时候, 未能做好水利水电工程资料的收 集工作, 导致水利水电工程设计与实际 情况不符, 难以保证水利水电工程建设 的顺利开展。在水利水电工程资料不足 的情况下, 设计人员无法掌握施工现场 的地质、水文等情况, 制定出的施工设计 方案缺乏针对性, 使得水利水电工程施 工中存在诸多隐患。其次, 在水利水电工 程设计的时候, 需要构建一个完整的工 程规划体系, 结合工程结构的情况进行
工程施工规划, 从而保证工程施工的整 体质量。但是就实际情况来看, 施工剖 面图不完善是水利水电工程设计中的 常见问题, 难以保证工程规划设计的全 面性, 使得水利水电工程的施工难度显 著提升 ${ }^{[1]}$ 。

\section{2 设计人员综合素质有待提升}

优秀的人才是促进水利水电工程设 计顺利进行的重要基础, 要求各个设计 人员具备良好的专业素质, 能够做到相 互沟通、相互配合, 及时对水利水电工程 设计中存在的问题进行处理, 从而提高 水利水电工程设计的水平。然而就实际 情况来看, 在以往水利水电工程设计过 程中, 设计人员比较依赖自身的工作经 验, 未能与其他工作人员进行有效沟通, 导致数据信息的交流不畅, 很容易出现 各种各样的问题, 使得水利水电工程设 计的实施效果受到影响。同时, 部分设计 人员的专业素质有待提升, 难以做到正 确处理水利水电工程设计中的问题, 甚 至会带来一些新的问题, 导致水利水电 工程的施工质量受到较大影响。

1.3 施工技术的创新力度不足

随着我国水利水电工程建设事业的 不断发展, 水利水电工程的种类越来越 多, 比如保护水文生态平衡的生态工程、 改善通航条件的港口航运工程、水力发
电和引水灌溉的水电工程等等, 这就使 得水利水电工程设计及施工面临着更多 挑战, 需要采取更加先进的技术手段来 促进工程施工的顺利进行, 实现提高工 程施工水平的目的。在进行水利水电工 程设计的时候, 设计人员需要充分了解 工程现场的情况, 对施工技术、施工材料 及施工设备也要加以重视, 利用一切因 素来解决施工问题, 保证工程施工的效 率及质量 ${ }^{[2]}$ 。但是就实际情况来看, 当前 水利水电工程施工依旧存在施工技术及 施工设计缺乏创新的情况, 难以适应水 利水电工程的不断发展。

\section{2 水利水电工程设计的改进对 策分析}

2.1做好工程资料的收集工作

为保证水利水电工程设计的整体质 量, 实现对水利水电工程建设质量的控 制, 需要对设计人员的工作理念进行转 变, 将全新的设计理念落实到各个环节, 促进水利水电工程设计的进一步发展。 在进行水利水电工程设计工作的过程中, 需要对工程施工区域的实际情况进行充 分了解, 以便能够进行科学合理的工程 设计, 实现对工程资源的合理分配。作为 水利水电工程设计的实施者, 设计人员 必须要严格做好施工现场的实地考察, 对地质、水文及周边生物等情况进行了 
解, 做好相关资料的收集工作, 将其作为 工程设计的重要依据。在完成工程资料 的收集工作之后, 可以借助这些资料进 行设计优化, 在提高工程施工质量的同 时, 降低工程施工的投入成本 ${ }^{[3]}$ 。

\section{2 加强设计人员的培训}

由于设计人员的能力水平对水利水 电工程设计的影响较大, 需要严格做好 设计人员的培训工作, 不断提高设计人 员的综合素质, 使其能够以良好的状态 完成工程设计, 避免因人为因素造成设 计不合理、设计不符合实际等情况。首 先, 需要对设计人员的知识结构进行完 善, 确保设计人员能够及时掌握相关的 新知识、新技术, 将其灵活运用到工程设 计中, 促进工程设计质量的提升。同时, 需要结合以往水利水电工程设计的情况 进行针对性地培训, 确保设计人员能够 正确处理工程设计中的重难点问题, 减 少工程设计问题的发生。其次, 需要做好 设计人员的思想教育工作, 不断强化设 计人员的工作责任感, 使其能够保持严 谨、细致的态度做好各项工作, 尤其要处 理好细节方面的处理, 从而保证水利水 电工程设计的实施效果。最后, 需要充分 发挥企业激励制度的作用, 促进设计人 员根据自身情况进行自主学习, 实现个 体与企业的共同发展。

\section{3 重视对新技术的运用}

在我国社会经济及科学技术的发展 背景下, 水利水电工程设计的复杂性不 断加大, 需要利用各种新技术来提高工 程设计的质量, 使工程建设的目标得以 顺利实现。具体来讲, 可以将各种先进的 技术应用到工程地质勘测活动中, 以此 确保勘测方式及勘测手段的有效性, 实
现提高勘测数据准确性的目的。只有做 好水利水电工程的现场勘测工作, 才能够 为工程设计提供可靠的数据支持, 减少工 程设计问题的发生。其次, 可以将各种先 进的技术应用到工程设计阶段, 比如利用 计算机信息技术构建完整的工程模型, 帮 助工作人员对水利水电工程设计进行综 合分析, 及时发现其中存在的问题, 并采 取有效措施进行处理, 从而保证水利水电 工程设计的科学性及合理性。

2. 4 注重生态理念与工程设计的融合 为适应我国可持续发展的要求, 在 进行水利水电工程设计的时候, 必须要 与生态理念相融合, 在保证工程质量的 同时, 对生态环境进行保护, 从而降低工 程建设对周边环境造成的影响。具体来 讲, 设计人员需要对旅游、生态等各方面 的功能进行考虑, 发挥水利水电工程对 调节生态环境的积极作用, 从而对城市 热岛效应进行控制, 使我国人民能够处 于更加舒适的生活环境。由于水利水电 工程对水资源的利用较大, 需要采取合 理的措施对河流湖泊等等进行保护, 并 保证水利工程的泄洪、储水等各方面的 能力达到要求, 从而发挥水利水电工程 的整体作用, 促进城市建设与自然环境 的协调发展。

2. 5加强工程设计过程的监管工作

在进行水利水电工程设计工作的时 候, 必须要安排专门的工作人员对整个 工程设计进行监管, 确保设计人员的行 为规范, 对工程设计中的问题进行有效 处理, 从而保证水利水电工程设计的整 体质量。在进行水利水电工程设计阶段 的监督工作时, 工作人员需要熟悉掌握 工程设计的内容, 严格控制好工程设计
的质量, 一旦发现工程设计存在不足, 应 督促设计人员及时进行整改, 确保工程 设计的进度和质量。同时, 需要重视设计 前的勘测工作能够顺利进行, 对有关工 程设计的注意事项进行标注, 尽可能提 高水利水电工程设计的可行性及规范性, 使其能够满足工程建设的要求。此外, 需要做好工程设计的审核工作, 对工程 设计中可能出现的问题进行分析, 便于 采取科学合理的改进对策, 促进水利水 电工程施工的顺利开展。

\section{3 结语}

综上所述, 随着我国水利水电工程 建设事业的不断发展, 水利水电工程设 计逐渐暴露出一定不足, 难以满足工程 建设的要求, 这就需要对其进行充分了 解, 做好工程资料的收集工作, 加强设计 人员的培训, 重视对新技术的运用, 注重 生态理念与工程设计的融合, 加强工程 设计过程的监管工作, 通过各种对策提 高工程设计水平, 为水利水电工程施工 的顺利开展提供有效支持。

\section{[参考文献]}

[1]田源.水利水电工程设计中常见 问题及对策研究 [J]. 建筑技术开 发,2020,47(15):10-12.

[2]周永军.水利工程设计中的常见 问题及解决对策经验分析 [J]. 智能城 市,2019,5(14):203-204.

[3]李飞燕.水利工程设计中存在的 问题及改进措施[J].河南水利与南水北 调,2019,48(04):53-54.

\section{作者简介:}

谢欣菲(1979--), 男, 汉族, 四川大竹 人,本科,工程师,研究方向: 水利水电工 程设计。 